shown that a varied assemblage of apes lived in the forests of northern India in the Miocene epoch. At that time the Himalayan Mountains did not exist, and the late Joseph Barrell ingeniously suggested that it may have been during the uplift of this mountain range at the end of the Miocene and beginning of the Pliocene that primitive man originated. As the land rose, the temperature would be lowered, and some of the apes which had hitherto lived in the warm forest would be trapped to the north of the raised area. As comparatively dry plains would there take the place of forests, and as the apes could no longer migrate southwards, those that survived must have become adapted for living on the ground, and acquired carnivorous instead of frugivorous habits. By continued development of the brain and increase in bodily size, such ground-apes would tend to become man.

Unfortunately, we are still ignorant of fossils to test this hypothesis. We know from fragments of jaws, isolated teeth, and one limb bone that generalised apes as large as chimpanzees existed in Europe so far north as the latitude of Darmstadt until the end of Miocene times, but the only giant ground-ape, which many have claimed to be an ancestral man, was found by Dubois in Java in deposits of much later age which may even be Pleistocene. Pithecanthropus erectus, as the Javan species is named, is still known only by a cranial roof, two molar teeth, and a diseased thigh-bone, which bear many resemblances to the corresponding parts of the existing gibbon, and are tantalising in their imperfection.

It is, however, curious that almost the only traces of true man hitherto found with distinctively ape-like characteristics are from Western Europe. The imperfect skull and mandible of Eoanthropus dawsoni discovered by the late Charles Dawson at Piltdown, Sussex, represents a man with the lowest of all known human brains, and with an ape-like jaw in which typically human molar teeth are accompanied by large canines as completely interlocking as in any ape. The massive lower jaw of Homo heidelbergensis from Mauer, near Heidelberg, still retains much reminiscence of an ape in its retreating chin. The fine skeleton of Neanderthal or Mousterian man described by Prof. Marcellin Boule from LaChapelle-aux-Saints, France, combines more apelike features in a single individual than are known in any existing man. The Piltdown and Heidelberg fossils are shown by associated mam. malian remains to date back at least to the beginning of the Pleistocene, perhaps even to the end of the Pliocente epoch. Neanderthal man is later, and is very soon followed by typical modern man.

As to the actual age of these various remains in years or centuries there has been much discussion, but it must be confessed that on present evidence only vague guesses are possible. It is true that Penck and Brückner have made some plausible suggestions as to the length of Pleistocene time based on their studies of the glaciation of the Alps. Baron de Geer has also been able to date more precisely the retreat of the Pleistocene ice-sheet in Scandinavia by counting the annual layers in the mud which its flood-waters left behind. It is impossible, however, with our present knowledge, to correlate the isolated patches of Piltdown gravel, Mauer sands, or cavern deposits with the surface phenomena of distant areas; and it is doubtful whether this difficulty will ever be overcome.

Our knowledge of the ancestry of man has, indeed, progressed much during recent years, but unfortunately it is necessary to depend on accidental discoveries. Systematic exploration seems to meet with little or no result. Mrs. Selenka made great and prolonged excavations in Java in the river-deposits whence Pithecanthropus was obtained, without any success. The great sandpit at Mauer has been continuously worked and most carefully watched since the famous jaw was discovered, but without recovering any further traces of man. I have worked. hard in the Piltdown gravel, but for the last three seasons I have not found a fragment of either bone or tooth. The research needs much patience, but we may hope that as interest in the subject is more widely spread a larger proportion of the accidental finds relating to it will escape destruction.

\title{
THE PRESENT POSITION OF THE MUTATION THEORY.
}

\section{By Prof. Hucio de Vries.}

D ARWIN assumed that species originate by the gradual accumulation of infinitesimal, ordinarily invisible variations on account of their utility in the struggle for life. The difficulties inherent in this conception have led to the theory of mutation, which supposes that the production of species and varieties proceeds by small but distinct steps, each step corresponding to one or more unit-characters. It is only after their appearance that the environment can decide about their utility.

The new theory reduced the time necessary for NO. 26 IO, VOL. IO4]. the evolution of organic life on earth to the limits deduced by Lord Kelvin and others from physical and astronomical data. It explained the appearance of the numerous useless qualities of animals and plants, and eliminated the objection that the first almost imperceptible changes could scarcely have any beneficial significance for their bearers. It developed the doctrine of two essential types of variability, which are now called fluctuating variability and mutability. The first of these describes the small but always present differences among individuals of the same stock, whereas 
the second is the way in which varieties are known to arise in horticulture and arboriculture.

Since the publication of my book on the mutation theory (190I-3) numerous instances of mutation have been observed by different investigators among animals as well as among plants. Half a dozen species of Enothera, some types of Primula, the walnut, the sunflower, Narcissus, Antirrhinum, Ligustrum, and many other instances might be cited. Among insects Morgan and his pupils have described more than a hundred mutations from the fruit-fly, Drosophila. Other cases have been studied by Tower for Leptinotarsa, etc.

The production of new races of agricultural crops by means of continual selection constituted for Darwin one of his strongest arguments. He showed conclusively that new species and varieties are produced in Nature in the same way as agricultural novelties. But at that time the practical method was far from being clearly understood. The work of Hjalmar Nilsson and Hays has since shown that selection may be conducted according to the principle of the mutation theory, only one choice being necessary to start the whole new variety.

It is now generally conceded by mutationists that the initial change takes place in the production of the sexual cells before fecundation. From this conception it follows that the chance of two similarly mutated cells to meet one another in this process must be very small, whereas ordinarily the mutated cells will combine with normal ones. This must produce half-mutants, and these may, in ordinary cases at least, split off the full mutants after the same rules which Mendel discovered for his hybrids. Sometimes the halfmutants will be distinct from their ancestors, as in Oenothera Lamarckiana rubrinervis and erythrina, and, therefore, will easily be discovered. In other instances external differences may be absent, and only the unexpected production of a new type in about $20-25$ per cent. or more of the individuals will betray the internal change. This explains the mass-mutations discovered by Bartlett. Such an indirect way of producing mutations by means of two successive steps seems to be very common in Nature, and will probably afterwards prove to be the general rule.

Willis has made an elaborate statistical study of the appearance of endemic species, which he considers to be the youngest of their region. $\mathrm{He}$ finds that utility of the new characters cannot have had any part in their production, since it cannot be shown to have any influence either on their first local extension or on their subsequent spreading over larger regions. Wide spreading is mainly the result of age, the oldest species having, as a rule, the largest areas. Moreover, in comparing the diagnoses of endemic species with the differences among the mutated forms of such a group as the evening primroses one finds a close parallelism, showing that our experimental mutations are quite analogous to the speciesproducing steps of Nature.

Objections against the mutation theory have been made by different investigators. Some systematists and palæontologists still adhere to the old view either wholly or only for special cases. Biologists rarely attack the theory in a direct way, but mainly discuss the question whether the observed mutations are really the representatives of the species producing changes in Nature, as is claimed. They assume that the splittings seen in our experiments are due to hybridism, and that every mutating species is a hybrid between supposed ancestors which possessed the mutative characters as specific marks. This idea can scarcely aid in simplifying the question, since it puts the origin of the characters involved on to unknown parents. Sterile varieties cannot produce hybrids, and therefore cannot originate in this way. This fact seems sufficient to disprove the hypothesis. In the case of the evening primroses this view has led to fantastic diagnoses of hypothetical ancestors, but even these fail to explain the facts observed in our cultures. Morgan's hypothesis of crossing over, which goes far to explain the splitting phenomena of the fruit-fly, fails in its application to the evening primroses, since here half-mutants are the rule. These must evidently be produced without the aid of that process. Moreover, the heterogamous mutants have dominant characters which are handed down by the egg-cells, and not by the pollen, instances of which are given by the mutations called lata, scintillans, cana, liquida, and others of Oenothera Lamarckiana. Evidently these can never be explained by the assumption of a hybrid condition of the parent species.

Thus we see that the broad arguments for the mutation theory are continually increasing in number, whereas the criticisms are more and more directed against special cases. They are concerned with the possibility of experimental proof and with the fitness of our material for further studies, but are not expected to invalidate the theory as such.

\section{THE PROGRESS OF MENDELISM.}

By Prof. W. Bateson, F.R.S.

GROM the discoveries to which the Mendelian clue immediately led, many lines of research and speculation are diverging. These enterprises have still aims in common, a fact which we recognise by including all under the one name, NO. 26 IO, VOL. IO4] genetics; for, though various in their methods, all relate to the physiology of breeding, a department of science the growth of which is a feature of the period surveyed on this occasion.

Stocktaking at the present moment is, however, 